Article

\title{
Potentials and Pitfalls on the Use of Passion Fruit By-Products in Drinkable Yogurt: Physicochemical, Technological, Microbiological, and Sensory Aspects
}

\author{
Nataly Maria Viva de Toledo ${ }^{1, *}$, Adriano Costa de Camargo ${ }^{1,2}$ (1), \\ Paula Bortolotto Mendes Ramos ${ }^{1}$, David Charles Button ${ }^{1,3}$, Daniel Granato 4 (iD) \\ and Solange Guidolin Canniatti-Brazaca ${ }^{1}$ \\ 1 Department of Agri-Food Industry, Food and Nutrition, "Luiz de Queiroz" College of Agriculture, \\ University of São Paulo, Av. Pádua Dias 11, P.O. Box 9, CEP 13418-900 Piracicaba, SP, Brazil; \\ adrianoesalq@gmail.com (A.C.d.C.); paulabmr@hotmail.com (P.B.M.R.); g29dcb@mun.ca (D.C.B.); \\ sgcbraza@usp.br (S.G.C.-B.) \\ 2 Department of Food Science and Technology, State University of Londrina, Rod. Celso Garcia Cid, PR 445, \\ km 380, Campus Universitário, P.O. Box 10.011, 86057-970 Londrina, PR, Brazil \\ 3 Marine Institute, Memorial University of Newfoundland, St. John's, NL A1C 5R3, Canada \\ 4 Department of Food Engineering, State University of Ponta Grossa, Av. Bonifácio Viléla, Centro, \\ CEP 84010-330 Ponta Grossa, PR, Brazil; granatod@gmail.com \\ * Correspondence: nataly.toledo@usp.br; Tel.: +55-19-3429-4150
}

Received: 18 May 2018; Accepted: 6 July 2018; Published: 8 July 2018

\begin{abstract}
Peels and seeds are the primary by-products of the passion fruit agroindustry. This study was designed to evaluate the potential of passion fruit peel and seeds flour (PFF) as a source of fiber and minerals to enhance the functional properties of drinkable yogurt. Proximate composition, mineral content, technological ( $\mathrm{pH}$, viscosity, color, and syneresis), and microbiological analyses (lactic acid bacteria, as well as yeast and mold counts), acceptance test, descriptive sensory analysis, and shelf life assessments were analyzed. Drinkable yogurts fortified with PFF showed higher fiber levels (both soluble and insoluble) and mineral content (potassium, magnesium, and manganese). Incorporation of PFF increased the viscosity and promoted changes in the color parameters of yogurts. During storage, the $\mathrm{pH}$ and the number of viable lactic acid bacteria decreased while the syneresis and yeast and mold counts increased. The shelf life of drinkable yogurts was estimated to be 21 days. Regarding sensorial aspects, drinkable yogurt fortified with $2 \%$ of PFF was considered the most viable product for market exploitation. The present contribution indicates that the use of passion fruit by-products in the development of drinkable yogurts is a viable alternative which can be explored for nutritional, technological, and sensory purposes by the food industry.
\end{abstract}

Keywords: passion fruit; fibers; mineral content; sensory evaluation; food waste; residues

\section{Introduction}

The passion fruit (Passiflora sp.) is native of tropical America and is cultivated in countries with tropical or subtropical climates. Brazil is one of the largest producers and consumers of passion fruit, but exports a large amount of fruit pulp to European and Asian countries. Despite its ample consumption, the economic relevance of passion fruit stems from its processing for juice-making [1].

The processing of foods and beverages comes along with the generation of many by-products. In the case of passion fruit, peels are the major by-products (about $52 \%$ of the total fruit weight), which is followed by its seeds [2]. Both by-products have an important nutritional value: the seeds have a high 
lipid content, especially unsaturated fatty acids (oleic and linoleic acids), while the peels are excellent sources of fiber, mainly pectins, and essential minerals, such as potassium and calcium [3].

Recent studies have demonstrated that fruit by-products (peels and seeds) may be helpful on decreasing the risk of chronic illnesses by decreasing the absorption of glucose and triacylglycerol, through inhibition of $\alpha$-glucosidase and lipase activities, respectively [4,5]. Experiments in rat models also showed that plant fruit by-products may be used as functional ingredients [6]. The literature has also supported the use of different fruit by-products as sources of antioxidants that may protect human-LDL from oxidation and DNA damage, these last two, being well known biomarkers for a potential development of cardiovascular diseases and certain types of cancer, respectively [5,7]. Plant food by-products have also shown antimicrobial effects towards Gram-positive and Gram-negative bacteria [8]. Moreover, the potential of passion fruit peel as a source of anti-inflammatory compounds is also well substantiated [9]. Therefore, the use of plant food by-products as a potential functional food ingredient is recommended.

Agro-industrial by-products have been intensely used in food enrichment, especially in terms of fiber content [10-13]. Fiber was identified as an "underconsumed nutrient of public health concern". Fiber intake lower than the recommended daily intake (RDI) can have several long-term negative health effects, such as an increased risk of coronary heart disease, stroke, obesity, hypertension, gastrointestinal diseases, and diabetes [14]. In this sense, the enrichment of products with fruit by-products can be an inexpensive method to increase fiber consumption $[15,16]$.

In addition to their nutritional contribution, fibers are typically added to foods to improve the technological aspects related to textural and structural properties, as well as increasing cook yields and water-holding capacity, and reducing lipid retention and caloric content $[17,18]$.

Drinkable yogurts are typically made from milk with addition of yogurt starter cultures, and they can be enriched with milk powder, fruits, grains, and proteins. In fact, the dairy industry and researchers are presently looking for products with lower fat content, with little or no sugar, and enriched with fiber $[19,20]$. Drinkable yogurt is a widely accepted product, however, the elaboration of dairy products enriched with fiber is still a challenge due to changes in their sensorial and technological properties [1,21].

Similarly, the introduction of different ingredients in drinkable yogurt formulations may affect the shelf-life of these highly-perishable foods. Although some studies [1,22] contemplate the use of passion fruit peel in yogurts, to the best of our knowledge no literature has focused on the use of both peel and seeds of passion fruit to fortify drinkable yogurt. Furthermore, a discussion of the nutritional point of view and the relevant aspects of the dairy industry should be considered. Therefore, the aim of the present study was to provide an alternative of application to the passion fruit by-products through the enrichment of drinkable yogurt with fruit by-products. Additionally, physicochemical, technological, microbiological, and sensory aspects of drinkable yogurt formulations were evaluated. In summary, the present contribution brings about the potentials and pitfalls on the use of passion fruit by-products to enhance the functionality in drinkable yogurt.

\section{Materials and Methods}

\subsection{Passion Fruit By-Products}

The by-products of passion fruit (peels and seeds) were provided by De Marchi Indústria e Comércio de Frutas Ltda (Jundiaí, SP, Brazil). In the industry, the fruits were washed, sanitized with sodium hypochlorite ( $200 \mathrm{mg} / \mathrm{L}$ solution), and washed again. The by-products were packed in polyethylene bags, transported, and stored $\left(-18^{\circ} \mathrm{C}\right)$ for up to 30 days.

\subsection{Passion Fruit Flour (PFF)}

Passion fruit peels and seeds were dehydrated in an oven (Fanem, São Paulo, Brazil) at $60{ }^{\circ} \mathrm{C}$ for $24 \mathrm{~h}$ (until reaching constant weight). After that, they were ground in a knife mill (Marconi, São Paulo, 
Brazil), and the flour obtained was passed through a 35-mesh sieve (Abronzinox, $0.425 \mathrm{~mm}$ ) to obtain a uniform material. The flour was packed in polyethylene bags, and frozen $\left(-18^{\circ} \mathrm{C}\right)$ for up to 30 days.

\subsection{Preparation of Milk and Drinkable Yogurt Manufacturing}

Drinkable yogurts were made according to the method described by Tamime and Robinson [23]. Cow whole milk (pasteurized, with $3 \%$ fat content, $\mathrm{pH}=6.7$, density at $15{ }^{\circ} \mathrm{C}=1.031 \mathrm{~g} / \mathrm{mL}$; Xandô, Fazenda Colorado, Araras, SP, Brazil), passion fruit pulp (pasteurized; Icefruit, Icefruit Comércio de Alimentos, Tatuí, SP, Brazil), skim milk powder (Molico, Nestlé Brasil Ltda., Araçatuba, SP, Brazil), refined sugar (União, Raízen Paraguaçu Ltda., Tarumã, SP, Brazil), and thermophilic lactic culture of Streptococcus thermophilus and Lactobacillus delbrueckii subsp. bulgaricus (lyophilized culture, Bio Rich, Chr. Hansen A/S, Horsholm, Denmark) were used. The products were acquired in a local market of Piracicaba, SP, Brazil.

The yogurt manufacturing process started with manual agitation $(1 \mathrm{~min})$ of the milk. Then, skim milk powder was added to adjust the total solids content to $16 \%$ [24]. The ingredients were manually homogenized for $5 \mathrm{~min}$. After that, the mixture was heated to $90{ }^{\circ} \mathrm{C}$ for $5 \mathrm{~min}$ and cooled in an ice water bath to $45^{\circ} \mathrm{C}$. Subsequently, it was inoculated with commercial starter culture $0.04 \%$ $(w / v)$ (manufacturer's recommendation) of thermophilic lactic culture. The yogurts were incubated in glass jars $(1 \mathrm{~L})$ at $45^{\circ} \mathrm{C}$. The titratable acidity was monitored until it reached $95^{\circ} \mathrm{D}$ and it was titrated with $0.1 \mathrm{~mol} / \mathrm{L} \mathrm{NaOH}$ solution until it reached a pH of 8.3 using a potentiometer (Gehaka, PG 1800, São Paulo, Brazil) and expressed as Dornic degree $\left(1^{\circ} \mathrm{D}=100 \mathrm{mg}\right.$ lactic acid/L) [25].

The yogurt jars were kept in containers with cold water $\left(10^{\circ} \mathrm{C}\right)$ for $15 \mathrm{~min}$. Afterward, the yogurt was refrigerated for $12 \mathrm{~h}$ to stabilize the gel, and then the following ingredients were added $(w / w): 20 \%$ of passion fruit pulp, $7 \%$ of refined sugar, and PFF, which was added in concentrations of $0 \%, 2 \%, 4 \%$, $6 \%$, or $8 \%$. A mixer apparatus (Philips Walita, RI1341, Hong Kong, China) was used to homogenize the samples ( $30 \mathrm{~s}$ ) and to create a drinkable yogurt texture. The products were kept enclosed in glass jars and stored at $5{ }^{\circ} \mathrm{C}$ until analysis. The processing occurred in triplicate (three independent yogurts were manufactured). In total, seven treatments were analyzed as follows:

(1) Commercial yogurt: plain drinkable yogurt acquired in the local market (reference material);

(2) Plain yogurt: experimental drinkable yogurt made without passion fruit pulp or PFF (control);

(3) Yogurt $0 \%$ : experimental drinkable yogurt made with $20 \%$ of passion fruit pulp and without PFF; and

(4) Yogurt $2 \%, 4 \%, 6 \%$, and $8 \%(w / w)$ : experimental drinkable yogurts made with $20 \%$ of passion fruit pulp and $2 \%, 4 \%, 6 \%$, or $8 \%(w / w)$ of PFF, respectively.

\subsection{Proximate Composition and Mineral Content}

Moisture (gravimetric), ash (gravimetric), protein (Kjedahl, $\mathrm{N} \times 6.25$ for passion fruit pulp and flour; $\mathrm{N} \times 6.38$ for yogurts), and lipids (Gerber for yogurt and ether extract for passion fruit pulp and flour) were determined according to AOAC [26]. Fiber (soluble and insoluble) was determined according to the enzymatic method described by Asp et al. [27]. The total carbohydrates were calculated by difference. The mineral content was determined through nitroperchloric digestion followed by inductively-coupled plasma-optical emission spectroscopy (ICP-OES, Jobin Yvon, JY50P Longjumeau, France). The analyses were performed in triplicate.

\subsection{Physicochemical Analyses}

The $\mathrm{pH}$ was evaluated by direct measurements in potentiometer for all drinkable yogurt samples and pulp. For the PFF, it was prepared a solution $(1: 10, w / v)$ with distilled water before using the potentiometer. The $\mathrm{pH}$ analyses of drinkable yogurts were carried out at 1, 7, 14, 21, and 28 days after production. Color parameters, such as lightness (L), hue angle (h), and chroma (C) were read using a colorimeter (CR-400, Chroma Meter, $8 \mathrm{~mm}$ in diameter, Konica Minolta Sensing, Tokyo, Japan) and 
a standard illuminant $\mathrm{C}$. The viscosity was determined using a rheometer (Brookfield DVIII Ultra Engineering Laboratories, Stoughton, MA, USA), with concentric cylinders, a SC4-31 spindle, with a rotational speed of $1 \mathrm{rpm}$, and six readings were collected every $20 \mathrm{~s}$ through Rheocalc 32 software (version 2.5, Brookfield Engineering Laboratories, Inc., Middleboro, MA, USA). The viscosity results were expressed in centipoise $(\mathrm{cP})$. To determine syneresis, $100 \mathrm{~mL}$ of drinkable yogurt was placed in a graduated cylinder and stored at $5{ }^{\circ} \mathrm{C}$ for 28 days. At different times $(7,14,21$, and 28 days) of storage, the volume of whey was measured. The results were expressed in percentage (\%) and were measured as $\mathrm{mL}$ of whey per $100 \mathrm{~mL}$ initial sample [28]. All physicochemical analyses were performed in triplicate. Parameters, such as color and viscosity, were determined $24 \mathrm{~h}$ after drinkable yogurt manufacturing.

\subsection{Microbiological Analyses}

Microbiological analyses were performed by diluting $25 \mathrm{~g}$ of sample in $225 \mathrm{~mL}$ of sterile peptone water $(0.1 \%)$ in a sterile plastic bag and blended using a stomacher (Seward Laboratory System, Bohemia, NY, USA) for 2 min. Escherichia coli counts were enumerated before the sensory evaluation, and it was determined by the multiple-tube fermentation test and expressed as most probable number (MPN)/g sample. Lactic acid bacteria (Streptococcus thermophilus, and Lactobacillus delbrueckii subsp. bulgaricus) counts were monitored during storage $(0,7,14,21$, and 28 days) by plating in Man, Rogosa, and Sharp agar. In addition, the samples were analyzed for yeast and mold in acidified potato dextrose agar medium. The results were expressed as colony forming units (log CFU)/g sample [29].

\subsection{Sensory Evaluation}

The present study was conducted in accordance with the Declaration of Helsinki, and the protocol was approved by the Committee on Ethics in Research of the "Luiz de Queiroz" College of Agriculture, University of São Paulo (Piracicaba, Brazil), under the project identification code no. 89. Two methods were chosen for the sensory evaluation of the formulations: acceptance test and descriptive analysis. The participants did not have any dietary restrictions for consuming any ingredients in the drinkable yogurt formulation. The drinkable yogurt samples were prepared $24 \mathrm{~h}$ before the sensory evaluation, and the samples were stored at $5{ }^{\circ} \mathrm{C}$ until analysis.

The panel consisted of 60 volunteers (adults, healthy, and non-smokers), students and employees from the University of São Paulo, aged between 18 and 60 years, mostly women (57\%), who declared to be consumers of yogurt ( $75 \%$ of panelists reported consuming yogurt at least once a week) and without subordination relationships with the members responsible for the research. Five samples $(0 \%$, $2 \%, 4 \%, 6 \%$, and $8 \%$ ) of drinkable yogurt $(30 \mathrm{~g})$ at $7{ }^{\circ} \mathrm{C}$ were presented in plastic cups previously coded with three-digit random numbers. The panelists evaluated the samples from left to right and drank water between them. The nine-point hedonic scale was used to express their overall impression [30]. The panelists were also invited to describe in an open question which attributes they liked and disliked about the drinkable yogurt. Samples were presented monadically, following a completely randomized block design.

The samples that obtained better acceptance (scores greater than 5 in the acceptance test) were used in descriptive sensory analysis [31]. Initially, 24 panelists participated in a pre-selection test that was performed to evaluate their ability to discriminate basic tastes. In the next stage, sequential analyses of the triangular test were used to verify the sensitivity of panelists in the detection of bitter and acidic tastes. Panelists received three samples with different concentrations of caffeine (bitter taste) or citric acid (acidic taste), being two identical (0.07\%) and one different (0.14\%). Individuals were asked to try the samples from left to right and identify the different one [32]. The panelists that obtained $100 \%$ accuracy in both tests were recruited.

Thus, 19 panelists were selected to define the descriptive terminology for the sensory attributes. They evaluated all samples that were presented in pairs and were asked to describe their impressions regarding the appearance, aroma, flavor, and texture. Through an open discussion, the panelists 
defined the relevant attributes that best described the drinkable yogurt samples, and a reference material with the definition of each attribute was elaborated for use during the training. The panelists were trained in sensory analysis of commercial drinkable yogurt using a 10-cm unstructured line scale, ranging from 'little' (score 0) to 'very' (score 10), to quantify the intensity of each attribute [32]. Panelists who demonstrated an ability at discriminating attributes, repeatability in the evaluation, and were in consensus with the group were selected for the final team.

The descriptive sensory analysis was conducted in two sessions, on different days, with three drinkable yogurts samples $(0 \%, 2 \%$, and $4 \%)$. The drinkable yogurts $(30 \mathrm{~g})$ were present at $7{ }^{\circ} \mathrm{C}$ in plastic cups previously coded with three-digit random numbers and introduced in a random manner in individual booths under white light. The final team was composed of 17 panelists, between 20 and 25 years, and mostly women (76\%). Compusense 5 software, version 5.2 (Compusense Inc., Guelph, ON, Canada) was used to compute the data.

\subsection{Statistical Analysis}

A completely randomized design was applied and data were expressed as means followed by the standard deviation. The software SAS-Statistical Analysis System, version 9.2 (SAS Institute Inc., Cary, NC, USA) was used to assess the intrinsic differences between treatments. For this purpose, data were subjected to analysis of variances (ANOVA) and the means were compared using the Tukey test $(p<0.05)$. Correlation analysis based on the Pearson's correlation coefficient was calculated to observe the association between responses.

\section{Results and Discussion}

\subsection{Proximate Composition}

The passion fruit flour (PFF), which was elaborated with non-edible parts of the fruit (peels and seeds) showed amounts of proteins, lipids, and fiber higher than that of the passion fruit pulp (Table 1). According to Morais et al. [3], peels and seeds of tropical fruits usually present higher amounts of nutrients, such as proteins, fiber, lipids, and minerals, than their pulps, which demonstrate their nutritional relevance for human nutrition. The main component of PFF was the dietary fiber $(64.0 \%)$ with insoluble fiber presenting the largest contribution $(50.4 \%)$ as compared to soluble fiber (13.6\%). Insoluble fiber plays an essential role in promoting regular bowel movement, which prevents constipation [33]. Fiber intake has also been correlated with the management of diabetes and the prevention of cardiovascular diseases, weight gain, and colorectal cancer [34-36].

The lipid and protein contents of PFF were $9.9 \%$ and $8.7 \%$, respectively. The ash content indicated that PFF might be a good source of minerals. The previous report about PFF indicated $5.8-7.2 \%$ for moisture, $5.2-7.1 \%$ for ash, $7.9-10 \%$ for protein, $42-57 \%$ for dietary fiber, and $0.7-5.64 \%$ for lipids in its composition $[3,10]$. These results are in accordance with the present study, except for the lipid content. Seeds are the main source of fatty acids in PFF, and their absence or smaller amount can interfere with the total lipid content [3]. Other factors, such as fruit variety, soil, and climate conditions for passion fruit production, and distinct formulations of the flour may also affect the PFF composition.

The addition of PFF resulted in a concurrent decrease in drinkable yogurt moisture, which was already expected due to the hygroscopic capacity of the fiber present in the passion fruit flour (64\%). When compared to the commercial yogurt, all treatments showed lower moisture values. The ash content increased in the drinkable yogurts due to the addition of PFF; this is supported by its high ash and mineral content (Table 1). Likewise, the lipid content increased with the addition of PFF, which was likely due to the seeds. According to Morais et al. [3], the lipid fraction present in passion fruit seeds renders a high content of unsaturated fatty acids from which linoleic (16\%) and oleic acids $(4.2 \%)$ are the major compounds. Unsaturated fatty acids are recognized for their potential to lower the risk of heart disease [37]. 
Table 1. Proximate composition, mineral content, color (L, C, and h), $\mathrm{pH}$ and viscosity parameters of passion fruit ingredients and drinkable yogurts.

\begin{tabular}{|c|c|c|c|c|c|c|c|c|c|}
\hline & \multicolumn{2}{|c|}{ Passion Fruit Ingredients } & \multicolumn{7}{|c|}{ Drinkable Yogurts } \\
\hline & Passion Fruit Pulp & $\begin{array}{c}\text { Passion Fruit Peel } \\
\text { and Seeds Flour }\end{array}$ & $\begin{array}{c}\text { Commercial } \\
\text { Yogurt }\end{array}$ & Plain Yogurt & Yogurt $0 \%$ PFF & Yogurt $2 \%$ PFF & Yogurt $4 \%$ PFF & Yogurt $6 \%$ PFF & Yogurt $8 \%$ PFF \\
\hline Moisture (g) & $90.0 \pm 1.3^{1}$ & $7.1 \pm 0.3$ & $82.0 \pm 0.0^{\mathrm{a} 2}$ & $77.4 \pm 0.2^{c}$ & $78.7 \pm 0.8^{b}$ & $77.7 \pm 0.6^{c}$ & $76.0 \pm 0.8^{\mathrm{d}}$ & $74.7 \pm 0.8^{\mathrm{e}}$ & $73.2 \pm 0.1^{\mathrm{f}}$ \\
\hline Ash $(g)$ & $0.7 \pm 0.0$ & $5.3 \pm 0.0$ & $0.8 \pm 0.0^{\mathrm{e}}$ & $1.3 \pm 0.0^{c}$ & $1.2 \pm 0.0^{\mathrm{d}}$ & $1.2 \pm 0.0^{\mathrm{cd}}$ & $1.3 \pm 0.1^{b}$ & $1.3 \pm 0.0^{b}$ & $1.4 \pm 0.0^{\mathrm{a}}$ \\
\hline Proteins (g) & $1.0 \pm 0.0$ & $8.7 \pm 0.3$ & $3.9 \pm 0.3^{\mathrm{a}}$ & $4.5 \pm 0.4^{\mathrm{a}}$ & $4.0 \pm 0.5^{\mathrm{a}}$ & $4.1 \pm 0.5^{\mathrm{a}}$ & $4.2 \pm 0.5^{\mathrm{a}}$ & $4.1 \pm 0.5^{\mathrm{a}}$ & $4.3 \pm 0.2^{\mathrm{a}}$ \\
\hline Lipids (g) & $0.5 \pm 0.0$ & $9.9 \pm 0.6$ & $2.8 \pm 0.0^{\mathrm{cd}}$ & $2.9 \pm 0.0^{\mathrm{ab}}$ & $2.4 \pm 0.0^{\mathrm{f}}$ & $2.6 \pm 0.0^{\mathrm{e}}$ & $2.7 \pm 0.0^{\mathrm{d}}$ & $2.9 \pm 0.0^{b c}$ & $3.0 \pm 0.0^{\mathrm{a}}$ \\
\hline Carbohydrates (g) & $6.1 \pm 1.1$ & $5.0 \pm 0.2$ & $10.5 \pm 0.1$ & $13.9 \pm 0.1$ & $13.4 \pm 0.6$ & $12.8 \pm 0.6$ & $13.0 \pm 0.8$ & $12.9 \pm 1.2$ & $12.8 \pm 0.4$ \\
\hline $\mathrm{DF}(\mathrm{g})$ & $1.7 \pm 0.2$ & $64.0 \pm 0.4$ & $0.0 \pm 0.0^{f}$ & $0.0 \pm 0.0^{\mathrm{f}}$ & $0.3 \pm 0.0^{\mathrm{e}}$ & $1.6 \pm 0.1^{\mathrm{d}}$ & $2.8 \pm 0.1^{\mathrm{c}}$ & $4.1 \pm 0.1^{b}$ & $5.3 \pm 0.2^{a}$ \\
\hline IDF (g) & $0.9 \pm 0.4$ & $50.4 \pm 0.4$ & $0.0 \pm 0.0^{\mathrm{e}}$ & $0.0 \pm 0.0^{\mathrm{e}}$ & $0.2 \pm 0.0^{\mathrm{e}}$ & $1.2 \pm 0.0^{\mathrm{d}}$ & $2.1 \pm 0.1^{\mathrm{c}}$ & $3.1 \pm 0.1^{b}$ & $4.0 \pm 0.2^{\mathrm{a}}$ \\
\hline $\mathrm{SDF}(\mathrm{g})$ & $0.8 \pm 0.2$ & $13.6 \pm 0.7$ & $0.0 \pm 0.0^{f}$ & $0.0 \pm 0.0^{\mathrm{f}}$ & $0.1 \pm 0.0^{\mathrm{e}}$ & $0.4 \pm 0.0^{\mathrm{d}}$ & $0.7 \pm 0.0^{c}$ & $1.0 \pm 0.0^{\mathrm{b}}$ & $1.3 \pm 0.0^{\mathrm{a}}$ \\
\hline $\mathrm{P}(\mathrm{mg})$ & $13.4 \pm 0.0$ & $11.6 \pm 1.1$ & $94.9 \pm 0.6^{f}$ & $131 \pm 2.2^{\mathrm{a}}$ & $122.4 \pm 0.4^{b}$ & $113.7 \pm 2.9^{\mathrm{e}}$ & $117.5 \pm 0.3$ de & $124.0 \pm 1.2^{b}$ & $118.9 \pm 0.8^{\mathrm{cd}}$ \\
\hline $\mathrm{K}(\mathrm{mg})$ & $172.9 \pm 3.8$ & $164.9 \pm 8.6$ & $133.1 \pm 0.3 \mathrm{~g}$ & $180.4 \pm 0.0^{\mathrm{f}}$ & $196.2 \pm 2.9^{\mathrm{e}}$ & $225.0 \pm 0.0^{\mathrm{d}}$ & $247.3 \pm 3.1^{c}$ & $306.5 \pm 0.0^{\mathrm{b}}$ & $316.2 \pm 3.6^{\mathrm{a}}$ \\
\hline $\mathrm{Ca}(\mathrm{mg})$ & $5.6 \pm 0.0$ & $21.7 \pm 1.5$ & $95.2 \pm 1.5^{\mathrm{e}}$ & $194.5 \pm 5.9^{\mathrm{a}}$ & $190.4 \pm 1.5^{\mathrm{a}}$ & $138.8 \pm 0.6^{\mathrm{d}}$ & $164.0 \pm 1.9^{b}$ & $160.7 \pm 0.0^{b}$ & $148.4 \pm 2.3^{c}$ \\
\hline $\mathrm{Mg}(\mathrm{mg})$ & 23. \pm 1.3 & $23.7 \pm 2.9$ & $8.4 \pm 1.1^{\mathrm{d}}$ & $10.2 \pm 1.4^{\mathrm{bcd}}$ & $9.5 \pm 0.0^{\mathrm{cd}}$ & $11.1 \pm 0.0^{\mathrm{bc}}$ & $12.6 \pm 0.0^{\mathrm{b}}$ & $15.7 \pm 0.0^{\mathrm{a}}$ & $15.3 \pm 1.4^{\mathrm{a}}$ \\
\hline $\mathrm{S}(\mathrm{mg})$ & $15.6 \pm 1.1$ & $12.3 \pm 1.1$ & $26.4 \pm 1.1^{\mathrm{d}}$ & $38.3 \pm 0.7^{\mathrm{a}}$ & $35.2 \pm 2.2^{c}$ & $35.3 \pm 0.7 b c$ & $36.1 \pm 0.4 \mathrm{abc}$ & $38.5 \pm 0.4^{\mathrm{a}}$ & $38.1 \pm 0.3 \mathrm{ab}$ \\
\hline $\mathrm{Na}(\mathrm{mg})$ & $15 \pm 1.7$ & $7.3 \pm 1.1$ & $41.9 \pm 2.5^{\mathrm{d}}$ & $72.2 \pm 0.0^{\mathrm{a}}$ & $59.7 \pm 2.9^{b}$ & $69.9 \pm 3.0^{\mathrm{a}}$ & $51.3 \pm 0.0^{c}$ & $56.5 \pm 3.4^{\mathrm{bc}}$ & $60.4 \pm 3.6^{\mathrm{b}}$ \\
\hline $\mathrm{Cu}(\mathrm{mg})$ & $0.1 \pm 0.0$ & $0.1 \pm 0.0$ & $0.1 \pm 0.0^{b}$ & $0.1 \pm 0.0^{\mathrm{ab}}$ & $0.0 \pm 0.0^{b}$ & $0.1 \pm 0.0^{\mathrm{ab}}$ & $0.1 \pm 0.0^{\mathrm{ab}}$ & $0.0 \pm 0.0^{\mathrm{b}}$ & $0.1 \pm 0.0^{\mathrm{a}}$ \\
\hline $\mathrm{Fe}(\mathrm{mg})$ & $0.8 \pm 0.3$ & $0.6 \pm 0.0$ & $0.5 \pm 0.2^{\mathrm{a}}$ & $0.4 \pm 0.1^{\mathrm{a}}$ & $0.5 \pm 0.2^{\mathrm{a}}$ & $0.6 \pm 0.3^{a}$ & $0.5 \pm 0.1^{\mathrm{a}}$ & $0.7 \pm 0.1^{\mathrm{a}}$ & $0.8 \pm 0.2^{a}$ \\
\hline $\mathrm{Mn}(\mathrm{mg})$ & $0.1 \pm 0.0$ & $0.3 \pm 0.0$ & $0.00 \pm 0.0^{\mathrm{e}}$ & $0.00 \pm 0.0^{\mathrm{e}}$ & $0.00 \pm 0.0^{\mathrm{e}}$ & $0.1 \pm 0.0^{\mathrm{cd}}$ & $0.1 \pm 0.0^{b c}$ & $0.2 \pm 0.0^{a b}$ & $0.2 \pm 0.0^{\mathrm{a}}$ \\
\hline $\mathrm{Zn}(\mathrm{mg})$ & $0.5 \pm 0.0$ & $0.4 \pm 0.0$ & $0.6 \pm 0.1^{\mathrm{a}}$ & $0.7 \pm 0.0^{\mathrm{a}}$ & $0.7 \pm 0.2^{\mathrm{a}}$ & $0.8 \pm 0.2^{\mathrm{a}}$ & $0.8 \pm 0.2^{\mathrm{a}}$ & $0.7 \pm 0.0^{\mathrm{a}}$ & $0.8 \pm 0.2^{\mathrm{a}}$ \\
\hline $\mathrm{L}$ & $48.4 \pm 0.1$ & $60.1 \pm 0.9$ & $77.0 \pm 0.5^{\mathrm{a}}$ & $76.3 \pm 0.0^{\mathrm{a}}$ & $73.9 \pm 0.3^{b}$ & $67.8 \pm 0.4^{c}$ & $64.7 \pm 0.6^{\mathrm{d}}$ & $60.8 \pm 1.1^{\mathrm{e}}$ & $59.4 \pm 1.0^{\mathrm{f}}$ \\
\hline C & $40.1 \pm 0.1$ & $31.6 \pm 1.2$ & $8.7 \pm 0.1^{\mathrm{d}}$ & $7.9 \pm 0.1^{\mathrm{e}}$ & 22. $\pm 0.4^{\mathrm{a}}$ & $19.6 \pm 0.2^{b}$ & $19.3 \pm 0.2^{b}$ & $18.2 \pm 0.8^{c}$ & $19.2 \pm 0.4^{b}$ \\
\hline $\mathrm{h}\left({ }^{\circ}\right)$ & $85.7 \pm 0.1$ & $82.5 \pm 1.5$ & $107.1 \pm 0.8^{\mathrm{a}}$ & $107.2 \pm 0.8^{a}$ & $96.7 \pm 0.1^{b}$ & $93.9 \pm 0.4^{c}$ & $92.2 \pm 0.9^{\mathrm{d}}$ & $91 \pm 0.5^{\mathrm{e}}$ & $90 \pm 0.5^{\mathrm{e}}$ \\
\hline $\mathrm{pH}$ & $3.20 \pm 0.03$ & $3.72 \pm 0.05$ & $4.05 \pm 0.03^{\mathrm{d}}$ & $4.57 \pm 0.02^{a}$ & $4.42 \pm 0.03^{b}$ & $4.31 \pm 0.02^{c}$ & $4.28 \pm 0.01^{c}$ & $4.26 \pm 0.02^{c}$ & $4.30 \pm 0.01^{\mathrm{c}}$ \\
\hline Viscosity $(\mathrm{cP})$ & NA & NA & NA & $6731 \pm 7.2^{\mathrm{d}}$ & $4918 \pm 5.9^{\mathrm{f}}$ & $5531 \pm 6.9^{e}$ & $7897 \pm 9.3^{c}$ & $11838 \pm 8.5^{b}$ & $21487 \pm 7.6^{\mathrm{a}}$ \\
\hline
\end{tabular}

${ }^{1}$ Data represent mean values for each sample \pm standard deviation $(n=3)$. For proximate composition and mineral content, the results are expressed on a fresh weight basis (100 g). ${ }^{2}$ Different letters as superscripts within rows for drinkable yogurts indicate that treatments differ significantly $(p<0.05)$. PFF: passion fruit peel and seeds flour. DF: dietary fiber. IDF: insoluble dietary fiber. SDF: soluble dietary fiber. NA: not available. 
Traditionally, yogurts do not contain a significant amount of fiber. The samples of plain drinkable yogurt, commercial yogurt, and drinkable yogurt $0 \%$, which did not present PFF in their composition, showed fiber contents lower than $0.5 \%$. On the other hand, drinkable yogurts with PFF showed a higher fiber content, which was in the range of $1.6-5.3 \%$. These results are supported by the proximate composition of PFF, which evidenced its role as a rich source of soluble and insoluble fiber and its great potential to increase the nutritional value of drinkable yogurts and other food products [18].

\subsection{Mineral Content}

In general, yogurts containing passion fruit pulp and flour showed a higher mineral content than the commercial formulation (Table 1). The addition of PFF and pulp in drinkable yogurt was able to increase the amount of phosphorus (from 13.5 to $17.7 \%$ ), potassium (from 2.8 to $6.7 \%$ ), calcium (from 9.5 to $16.4 \%$ ), magnesium (from 2.5 to $4.6 \%$ ), iron (from 6.2 to $8 \%$ ), and zinc (from 7.5 to $10 \%$ ). Additionally, according to the recommendations of the National Institutes of Health [38], the intake of $100 \mathrm{~g}$ of drinkable yogurt containing PFF (yogurt 2-8\%) would provide $16.2-17.7 \%$ of phosphorus, $11.6-16.4 \%$ of calcium, $4.8-6.7 \%$ of potassium, $3.4-5.8 \%$ of sodium, and $2.6-5 \%$ of magnesium recommended daily intake (RDI) for men and women, respectively, between 19 and 70 years. Considering that minerals should be provided not only by yogurt, but from a balanced diet, our drinkable yogurt formulation may be helpful to increase the intake of minerals when combined with other sources of minerals, which, in turn, may render health benefits.

\subsection{Physicochemical Analyses}

Yogurt $0 \%$ (with pulp but devoid of PFF) and those with pulp and different concentration of PFF (2-8\%) showed a lower $\mathrm{pH}$ than plain drinkable yogurt (Table 1), which is explained by the $\mathrm{pH}$ of the pulp (3.20) and PFF (3.72). At the first day of storage (Table 1), no differences were observed among drinkable yogurts with PFF (2-8\%). During storage (Table 2), the $\mathrm{pH}$ values recorded were from 3.99 to 4.57 for the drinkable yogurt samples. This decrease was already expected and probably occurred due to the symbiotic relation between Streptococcus thermophilus and Lactobacillus delbrueckii subsp. bulgaricus, which are homofermentative bacteria that present high metabolic activity [11,39]. The same behavior was observed by other studies that reported a pH range from 4.0 to 4.6 in different drinkable yogurt samples [11,40].

Table 2. Effect of passion fruit flour (PFF) addition on $\mathrm{pH}$ and syneresis of drinkable yogurts stored at $5{ }^{\circ} \mathrm{C}$ for $7,14,21$, and 28 days.

\begin{tabular}{|c|c|c|c|c|}
\hline \multicolumn{5}{|c|}{$\mathrm{pH}$} \\
\hline \multirow[t]{2}{*}{ Drinkable yogurt with PFF (\%) } & \multicolumn{4}{|c|}{ Storage time (days) } \\
\hline & 7 & 14 & 21 & 28 \\
\hline Plain* & $4.57 \pm 0.01^{1 \mathrm{a} 2 \mathrm{~A} 3}$ & $4.46 \pm 0.01^{\mathrm{aB}}$ & $4.34 \pm 0.02^{\mathrm{aC}}$ & $4.30 \pm 0.02^{\mathrm{aC}}$ \\
\hline 0 & $4.42 \pm 0.01 \mathrm{bA}$ & $4.29 \pm 0.01^{\mathrm{bB}}$ & $4.05 \pm 0.01^{\mathrm{cC}}$ & $4.01 \pm 0.01 \mathrm{bD}$ \\
\hline 2 & $4.31 \pm 0.01 \mathrm{cA}$ & $4.19 \pm 0.02 \mathrm{cdB}$ & $4.08 \pm 0.01 \mathrm{bC}$ & $3.99 \pm 0.01^{b D}$ \\
\hline 4 & $4.28 \pm 0.02 \mathrm{cdA}$ & $4.17 \pm 0.01 \mathrm{~dB}$ & $4.05 \pm 0.02 \mathrm{bcC}$ & $4.00 \pm 0.03 \mathrm{bD}$ \\
\hline 6 & $4.26 \pm 0.02 \mathrm{dA}$ & $4.16 \pm 0.02 \mathrm{~dB}$ & $4.04 \pm 0.01 \mathrm{cC}$ & $4.03 \pm 0.01 \mathrm{bC}$ \\
\hline 8 & $4.30 \pm 0.02^{\mathrm{cdA}}$ & $4.20 \pm 0.01 \mathrm{cB}$ & $4.09 \pm 0.01 \mathrm{bC}$ & $4.03 \pm 0.01 \mathrm{bD}$ \\
\hline \multicolumn{5}{|c|}{ Syneresis (\%) } \\
\hline \multirow[t]{2}{*}{ Drinkable yogurt with PFF (\%) } & \multicolumn{4}{|c|}{ Storage time (days) } \\
\hline & 7 & 14 & 21 & 28 \\
\hline Plain * & $25.0 \pm 0.6^{\mathrm{aC}}$ & $31.5 \pm 0.5^{\mathrm{aB}}$ & $39.2 \pm 0.6^{\mathrm{aA}}$ & $41.7 \pm 1.8^{\mathrm{aA}}$ \\
\hline 0 & $24.0 \pm 1.0 \mathrm{aB}$ & $28.8 \pm 0.3 \mathrm{bA}$ & $31.3 \pm 1.6^{\mathrm{bA}}$ & $32.0 \pm 2.2^{\mathrm{bA}}$ \\
\hline 2 & $17.0 \pm 0.6^{\mathrm{bD}}$ & $22.5 \pm 0.5^{\mathrm{acC}}$ & $26.9 \pm 1.0 \mathrm{cB}$ & $31.1 \pm 0.8^{\mathrm{bA}}$ \\
\hline 4 & $12.2 \pm 0.9 \mathrm{cD}$ & $17.6 \pm 0.4 \mathrm{dC}$ & $20.8 \pm 0.2^{\mathrm{dB}}$ & $22.7 \pm 0.4 \mathrm{cA}$ \\
\hline 6 & $2.50 \pm 0.2 \mathrm{dC}$ & $6.30 \pm 0.3^{\mathrm{eB}}$ & $8.80 \pm 0.3^{\mathrm{eA}}$ & $9.40 \pm 0.3^{\mathrm{dA}}$ \\
\hline 8 & $2.20 \pm 0.1 \mathrm{~dB}$ & $2.20 \pm 0.1^{\mathrm{fB}}$ & $2.80 \pm 0.3^{\mathrm{fA}}$ & $3.20 \pm 0.3^{\mathrm{eA}}$ \\
\hline
\end{tabular}

${ }^{1}$ Data represent mean values for each sample \pm standard deviation $(n=3) .{ }^{2}$ Means followed by different lower case letters within a column show difference between drinkable yogurts $(p<0.05) .{ }^{3}$ Means followed by different capital letters within a row show difference between storage times $(p<0.05)$. PFF: passion fruit peel and seeds flour. * Plain yogurt: experimental drinkable yogurt made without passion fruit pulp or PFF. 
Regarding the syneresis, it was observed that the plain drinkable yogurt and the drinkable yogurt with $8 \%$ PFF showed the highest and the lowest syneresis percentages, respectively (Table 2). In general, the syneresis increased during the storage time, but there was no difference between the 21 st and 28th day of storage (except for the drinkable yogurts with $2 \%$ and $4 \%$ of PFF). During the storage, $\mathrm{pH}$ values decreased while the syneresis values increased (Table 2). Similar observations were reported by García-Perez et al. [39] and Hashim et al. [41], which was expected because as the milk is acidified, the charges on caseins decrease, which weakens the electrostatic forces holding micelles together, and weakens the steric stabilization. This decreases the attractive force between micelles, which become 'adhesive' or 'sticky' and forms a weak particle gel with serum separation [42].

Treatments with higher PFF concentrations remained more stable and lowered syneresis due to the high fiber content and its water-holding capacity that absorbed the whey released by the gel structure [39]. According to Ramirez-Santiago et al. [43], the addition of 1\% yam soluble fiber (YSF) extracted from Pachyrhizus erosus L. reduced the syneresis of stirred yogurt and rendered a more acceptable mouthfeel compared to the control yogurt (devoid of YSF). Tseng and Zhao [40] used wine grape pomace (WGP) as a source of dietary fiber and verified that the addition of $1 \%$ and $2 \%$ WGP rendered yogurts that were more stable regarding syneresis during three weeks of storage.

Color is one of the most important quality parameters for the consumer acceptance of foods [10]. Drinkable yogurts became darker (Table 1) with the addition of PFF as demonstrated by the lightness value (L). As for the chroma (C), drinkable yogurts with PFF showed lower values than the samples devoid of PFF (yogurt $0 \%$ ). Likewise, the hue angle (h) value decreased with a concurrent increase in the concentration of PFF. This parameter indicated that these samples presented yellow tonality. Yogurt $0 \%$ and yogurt $8 \%$ showed, respectively, the strongest and weakest yellow intensities and this demonstrated that even at low concentrations PFF affected the color of the samples. The color of yogurt depends on its $\mathrm{pH}$ [39]. It can be observed that parameters, such as $\mathrm{L}$ and $\mathrm{h}$, had a positive correlation with $\mathrm{pH}(\mathrm{r}=0.883$ and $\mathrm{r}=0.857$, respectively), while the parameter $\mathrm{C}$ presented negative correlation $(\mathrm{r}=-0.734)$. In all cases, it was noted that PFF addition influenced drinkable yogurt color. Other studies $[21,39,41]$ that used by-products in yogurt formulations also commented on changes in the color parameters of their products.

Concerning the drinkable yogurt viscosity, it was observed that the drinkable yogurt with pulp, but without PFF (yogurt $0 \%$ ), present the lowest viscosity value while the yogurt $8 \%$ demonstrated the highest one. The addition of PFF increased the viscosity of the samples due to the high content of fiber (64.0\%). A similar result was observed by Arioui et al. [11] in yogurt fortified with Citrus sinensis peels and the best viscosity value was obtained with $0.6 \%$ of pectin. Aportela-Palacios et al. [44] stated that wheat bran is a great option as a fiber source to increase the viscosity and consistency of yogurts. Despite the effects of fiber addition on the viscosity, the texture of drinkable yogurt can also be affected by other factors such as casein content of the milk, firmness of the gel before stirring, the intensity of stirring, and syneresis [45].

\subsection{Microbiological Evaluation}

E. coli counts were $<3 \mathrm{MNP} / \mathrm{g}$ for all treatments, which is within the established limits (10 MNP/g) [46]. During storage, the lactic acid bacteria count was monitored (Table 3). Plain drinkable yogurt had the highest number of lactic acid bacteria, but PFF addition was not correlated with the lactic acid bacteria count $(r=-0.0269)$; therefore, the flour addition did not impair the drinkable yogurt shelf life. Perina et al. [22] also reported on the use of passion fruit by-products in yogurt formulation and they did not observe any influence of PFF on lactic acid bacteria. 
Table 3. Lactic acid bacteria, yeast, and molds of drinkable yogurt samples stored at $5{ }^{\circ} \mathrm{C}$ during 28 days.

\begin{tabular}{|c|c|c|c|c|c|c|}
\hline \multirow{2}{*}{$\begin{array}{l}\text { Storage Time } \\
\text { (days) }\end{array}$} & \multicolumn{6}{|c|}{ Drinkable Yogurt with PFF (\%) } \\
\hline & Plain * & $\mathbf{0}$ & 2 & 4 & 6 & 8 \\
\hline \multicolumn{7}{|c|}{ Lactic acid bacteria $(\log C F U / g)$} \\
\hline 0 & $8.63^{1 \mathrm{a} 2 \mathrm{~A} 3}$ & $8.38^{\mathrm{dA}}$ & $8.45^{\mathrm{cA}}$ & $8.34 \mathrm{dA}$ & $8.49 \mathrm{bA}$ & $8.32 \mathrm{dA}$ \\
\hline 7 & $8.43^{\mathrm{aB}}$ & $8.11^{\mathrm{cB}}$ & $8.28^{b B}$ & $7.99 \mathrm{~dB}$ & $8.30 \mathrm{bB}$ & $8.04^{\mathrm{cdB}}$ \\
\hline 14 & $7.92 \mathrm{aC}$ & $7.69 \mathrm{dC}$ & $7.75^{b C}$ & $7.72 \mathrm{cC}$ & $7.63 \mathrm{eC}$ & $7.61^{\mathrm{eC}}$ \\
\hline 21 & $7.60^{\mathrm{aD}}$ & $7.23^{\mathrm{dD}}$ & $7.25 \mathrm{dD}$ & $7.41^{\mathrm{cD}}$ & $7.46^{\mathrm{bC}}$ & $7.04^{\mathrm{eD}}$ \\
\hline 28 & $6.99 \mathrm{aE}$ & $6.82 \mathrm{dE}$ & $6.81^{\mathrm{dE}}$ & $6.86^{\mathrm{cE}}$ & $6.89 \mathrm{bE}$ & $6.72 \mathrm{eE}$ \\
\hline \multicolumn{7}{|c|}{ Yeast and mold $(\log$ CFU/g) } \\
\hline 0 & $<1^{\mathrm{aC}}$ & $<1^{\mathrm{aC}}$ & $<1 \mathrm{Ad}$ & $<1^{\mathrm{aD}}$ & $<1^{\mathrm{aD}}$ & $<1^{\mathrm{aD}}$ \\
\hline 7 & $<1$ aC & $<1^{\mathrm{aC}}$ & $<1 \mathrm{aD}$ & $<1$ aD & $<1 \mathrm{aD}$ & $<1$ aD \\
\hline 14 & $<1 \mathrm{dC}$ & $<1 \mathrm{dC}$ & $1.68^{\mathrm{cC}}$ & $1.64^{\mathrm{cC}}$ & $1.84^{\mathrm{bC}}$ & $1.92^{\mathrm{aC}}$ \\
\hline 21 & $1.43^{\mathrm{fB}}$ & $1.62^{\mathrm{eB}}$ & $1.99 \mathrm{~dB}$ & $2.11^{\mathrm{cB}}$ & $2.20 \mathrm{bB}$ & $2.25^{\mathrm{aB}}$ \\
\hline 28 & $1.94 \mathrm{eA}$ & $2.15^{\mathrm{dA}}$ & $2.40^{\mathrm{cA}}$ & $2.61 \mathrm{bA}$ & $2.59 \mathrm{bA}$ & $2.71^{\mathrm{aA}}$ \\
\hline
\end{tabular}

A decrease in lactic acid bacteria count was observed during storage, which may be related to the low $\mathrm{pH}$ post-acidification. Streptococcus thermophilus and Lactobacillus delbrueckii subsp. bulgaricus live in a mutual stimulation that is related to the growth, acidification, and the production of aromatic compounds. After fermentation, organic acid accumulation (e.g., lactic and acetic acid) occurs. Organic acids are powerful antimicrobial agents; therefore, they may affect the survival of microorganisms [47]. Additionally, L. bulgaricus is more sensitive to storage than S. thermophilus, and it usually presents a large decrease in its viable cells [1]. For yogurt, the sum of microorganisms in the starter culture must be at least $10^{7}$ (CFU/g) [48]. As demonstrated in Table 3, all samples had adequate amounts of viable lactic acid bacteria until the 21st day of storage. Therefore, the present formulations are satisfactory for three weeks, which defines the product shelf life.

Although some microbiological aspects of yogurts fortified with passion fruit by-products have already been investigated [1] no attention has been paid to the presence of yeast and mold growing, which may also impair the product shelf life. The present study demonstrated that the addition of passion PFF may contribute to the growth of yeast and mold in drinkable yogurt (Table 3). Contamination by yeast and molds is a major problem faced by the dairy industry. According to Ledenbach and Marshall [49], yeast and mold can promote changes in sensory characteristics of yogurt, like yeasty and fermented off-flavors and a gassy appearance. The authors stated that yogurts elaborated under conditions of good manufacturing practices should contain no more than 10 yeast cells and should present a shelf life of $3-4$ weeks at $5{ }^{\circ} \mathrm{C}$. For the present drinkable yogurt formulation, yeast and mold counts were higher than this recommendation after 21 days of storage.

In order to increase the drinkable yogurt shelf life, it is suggested that the use of plant food by-products should come along with additional processes, such as gamma-irradiation to ensure microbiological decontamination; or drying, that may be helpful to reduce the water activity of the product, making the growth of spoilage and pathogenic microorganisms more difficult [50]. In addition, the use of other technologies, such as UV pasteurization, is also recommended to increase the shelf life of beverages [51]. 


\subsection{Sensory Evaluation}

The sensory acceptance test demonstrated that the drinkable yogurt with the highest PFF concentration (yogurt $8 \%$ ) generated the lowest score given by the panelists (Figure 1A). However, concentrations up to $4 \%$ received scores higher than five, indicating that panelists accepted the sample. According to the panelists, the yogurt $0 \%$ and $2 \%$ presented a pleasant and light flavor with a good texture and appearance, whereas the yogurt $8 \%$ was described as bitter, showing a heterogeneous texture with perceptible granules. Furthermore, it is important to highlight that the yogurt $8 \%$ presented the lowest moisture content (Table 1), which may interfere in its texture and be a rejection factor for the consumer [52]. Many panelists stated they would consume the yogurt $2 \%$ due to its association with a healthier diet because they perceived and liked the presence of fiber in the drinkable yogurt formulation. According to Gahruie et al. [53], despite the fiber-related health benefits, it is important to note that consumers do not usually accept formulations with more than $3 \%$ fiber.
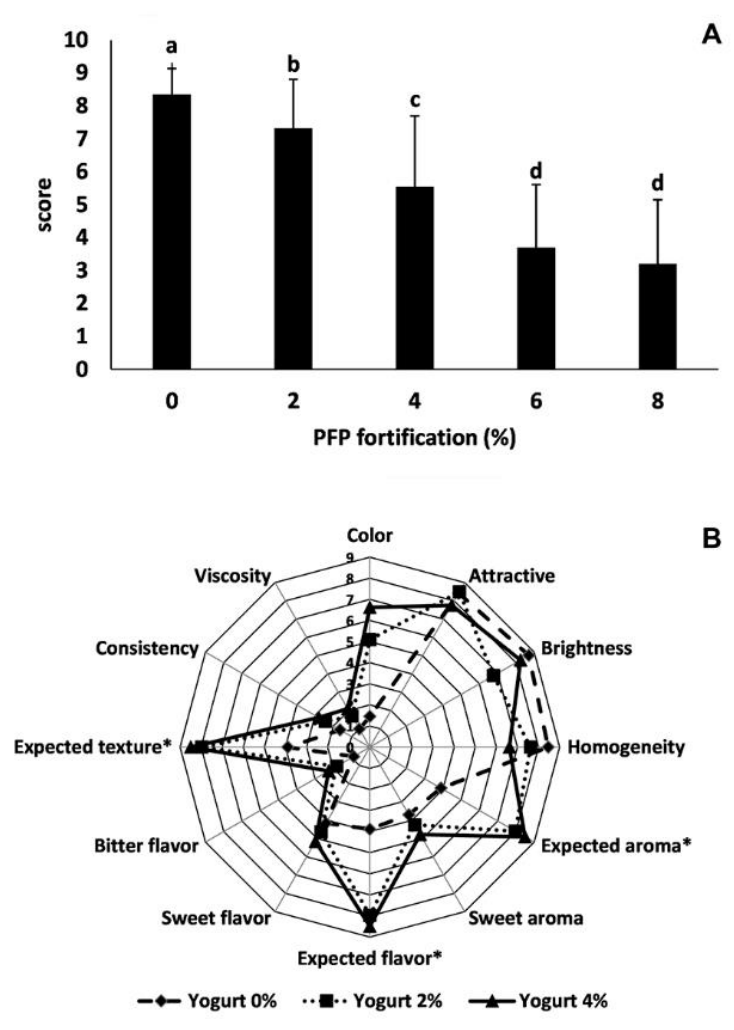

Figure 1. Sensory acceptance (A) and sensory profile (B) of passion fruit drinkable yogurts. Different lowercase letters (A) indicate that treatments differ significantly $(p<0.05)$. PFF: passion fruit peel and seeds flour. * When compared to a passion fruit-based yogurt.

Sensory descriptive analysis was also performed to provide the sensory profile of the drinkable yogurt. For this test, drinkable yogurts with pulp and PFF concentrations of 0 , 2, and $4 \%$ of PFF were used because they received higher acceptance (scores $>5$ in the acceptance test). The panelists described their perceptions about the product. In-group consensus descriptive terms, definitions, and references were defined for the following attributes: appearance (colorful, attractive, bright, and homogeneous), aroma (expected and sweet), flavor (expected, sweet, and bitter), and texture (expected, consistent, and viscous) (Table 4). After the training sessions, the panelists participated in the final stage of the descriptive analysis. In many attributes, the drinkable yogurts with PFF (yogurt $2 \%$ and $4 \%$ ) presented significant differences compared to the drinkable yogurt devoid of PFF (yogurt $0 \%$ ) (Figure 1B). Therefore, the PFF was responsible for the different attributes that were not exhibited in the traditional product (yogurt $0 \%$ ), which may be an innovation for the dairy products market. 
Table 4. Definitions of terms and reference materials used in the sensory descriptive analysis.

\begin{tabular}{|c|c|c|}
\hline $\begin{array}{l}\text { Descriptive Terms } \\
\text { (Attributes) }\end{array}$ & Definition & Reference \\
\hline \multicolumn{3}{|c|}{ Appearance } \\
\hline 2. Attractiveness & Refers to the desire to consume the drinkable yogurt & $\begin{array}{l}\text { - Little: drinkable yogurt with } 8 \% \text { of PFF (not sifted flour) and not } \\
\text { homogenized in the mixer apparatus } \\
\text { - Very: fresh drinkable yogurt and homogenous (control) }\end{array}$ \\
\hline 3. Brightness & Refers to color lightness & $\begin{array}{l}\text { - Little: drinkable yogurt (control) stored uncovered in the } \\
\text { refrigerator for } 72 \mathrm{~h} \text { and with low moisture } \\
\text { - Very: fresh drinkable yogurt (control) }\end{array}$ \\
\hline 4. Homogeneity & $\begin{array}{l}\text { Refers to the uniformity of the drinkable yogurt; } \\
\text { there aren't black spots, bubbles, or fibers }\end{array}$ & $\begin{array}{l}\text { - Little: drinkable yogurt with } 8 \% \text { of PFF (not sifted flour) and not } \\
\text { homogenized in the mixer apparatus } \\
\text { - Very: non-fat milk }\end{array}$ \\
\hline \multicolumn{3}{|c|}{ Aroma } \\
\hline 5. Expected & $\begin{array}{l}\text { Refers to the aroma of a drinkable yogurt with fiber } \\
\text { when compared to a passion fruit-based yogurt }\end{array}$ & $\begin{array}{l}\text { - Little: commercial drinkable yogurt that has fiber in its } \\
\text { composition (Activia, Danone) added with } 5 \% \text { vinegar } \\
\text { - Very: drinkable yogurt with passion fruit pulp and flour }\end{array}$ \\
\hline 6. Sweet & Refers to the drinkable yogurt's sweetness & $\begin{array}{l}\text { - Little: plain drinkable yogurt (control) } \\
\text { - Very: plain drinkable yogurt (control) with } 15 \% \text { of sugar and } \\
\text { vanilla essence }\end{array}$ \\
\hline \multicolumn{3}{|c|}{ Flavor } \\
\hline 7. Expected & $\begin{array}{l}\text { Refers to the flavor of a drinkable yogurt with fiber } \\
\text { when compared to a passion fruit-based yogurt }\end{array}$ & $\begin{array}{l}\text { - Little: commercial drinkable yogurt (Activia, Danone) that has } \\
\text { fiber in its composition and added with } 5 \% \text { vinegar } \\
\text { - Very: drinkable yogurt with passion fruit pulp and flour }\end{array}$ \\
\hline \multicolumn{3}{|c|}{ Texture } \\
\hline 10. Expected & $\begin{array}{l}\text { Refers to the texture of a drinkable yogurt with fiber } \\
\text { when compared to a passion fruit-based yogurt }\end{array}$ & $\begin{array}{l}\text { - Little: non-fat milk } \\
\text { Very: commercial drinkable yogurt that has fiber in its } \\
\text { composition (Activia, Danone) }\end{array}$ \\
\hline 11. Consistency & Refers to the firmness of the drinkable yogurt & $\begin{array}{l}\text { - } \quad \text { Little: non-fat milk } \\
\text { - } \quad \text { Very: commercial vanilla flan (Vigor) }\end{array}$ \\
\hline 12. Viscosity & Refers to the slip resistance of the drinkable yogurt & $\begin{array}{l}\text { - Little: non-fat milk } \\
\text { - } \quad \text { Very: milk added with } 10 \% \text { wheat flour }\end{array}$ \\
\hline
\end{tabular}

A brownish color was observed in drinkable yogurts with PFF, but the darkening of the samples did not compromise the attribute 'attractive', which received satisfactory scores (all above 8.0) for all treatments. No differences were found in the 'brightness' attribute between the drinkable yogurts manufactured with $2 \%$ and $4 \%$ PFF and these samples even presented higher scores for this attribute compared to the control.

The drinkable yogurts with PFF presented a high intensity of expected aroma, expected flavor, and expected texture, and the drinkable yogurts (2\% and $4 \%)$ did not present statistical differences. The addition of PFF increased the intensity of sweet aroma and flavor, and the yogurt $4 \%$ showed the highest score for both attributes ( 4.52 and 4.63 , respectively). The panelists have also identified a slightly bitter taste in drinkable yogurts, which may be explained by the presence of phenolic compounds in passion fruit mesocarp [54]; therefore, the samples presented low scores for this attribute (less than 2.40). Significant differences were found among all treatments, and the scores for bitter taste were proportional to the PFF concentration. In a yogurt formulation developed by Perina et al. [22], 
panelists noted a bitter taste for yogurt that may be considered a driver of disliking when in excess, and the authors associated this bitter taste to the addition of strawberry pulp and unflavored passion fruit peel-powder.

No differences were observed on the consistency and viscosity between yogurt $2 \%$ and $4 \%$, and both presented higher scores as compared with yogurt $0 \%$. This fact is associated with the higher fiber contents of such samples, which may be responsible for the thick and viscous texture. Perina et al. [22] did not find significant differences between the texture of yogurts with passion fruit peel and seeds flour and the control. However, Raju and Pal [21] observed that yogurt fortified with $1.5 \%$ of soy fiber or oat fiber present lower scores for texture than the control.

\section{Conclusions}

Drinkable yogurts with PFF showed high levels of fiber (mainly insoluble ones) and minerals when compared to the control yogurt. The addition of PFF can increase the drinkable yogurt's viscosity and decrease the syneresis due to the respective increase of fiber in drinkable yogurts. During storage, the $\mathrm{pH}$ and the number of viable lactic acid bacteria decreased, while the syneresis increased and the estimated shelf life of the product was 21 days. The addition of passion fruit flour was associated with the growth of yeast and mold in drinkable yogurts; therefore, it is recommended that some previous treatment should be carried out in the flour before its use. Regarding the sensorial aspect, it was noted that drinkable yogurt with $2 \%$ of PFF received a satisfactory acceptance. The sensory descriptive analysis confirmed that the addition of pulp and PFF influenced the drinkable yogurt sensory profile and the treatments with $2 \%$, and $4 \%$ of PFF presented the highest scores for most desirable attributes for passion fruit drinkable yogurt enriched with fiber. Due to its satisfactory sensory acceptance, sensory profile, and physicochemical characteristics, the $2 \%$ yogurt was considered the most viable product for the exploitation of the dairy market.

Author Contributions: Conceptualization, methodology, and resources: N.M.V.d.T., P.B.M.R., and S.G.C.-B.; formal analysis and investigation: N.M.V.d.T., P.B.M.R.; data curation: S.G.C.-B. and A.C.d.C.; writing-original draft preparation: N.M.V.d.T.; writing—review and editing: S.G.C.-B., A.C.d.C., D.C.B., and D.G.; supervision: S.G.C.-B.; and project administration and funding acquisition: N.M.V.d.T. and S.G.C.-B.

Funding: This research was funded by FAPESP (São Paulo Research Foundation) (grant \#2010/14042-9). A. C. de Camargo acknowledges FAPESP (São Paulo Research Foundation) for granting his PhD fellowship (grant \#2012/17683-0), as well as CAPES for his PNPD postdoctoral fellowship. D. Granato thanks CNPq for a productivity grant (grant \#303188/2016-2).

Acknowledgments: The authors acknowledge De Marchi industry for providing the passion fruit by-products and Ernani Porto (in memoriam) for his valuable contribution to this research.

Conflicts of Interest: The authors declare no conflict of interest. The founding sponsors had no role in the design of the study; in the collection, analyses, or interpretation of data; in the writing of the manuscript; or in the decision to publish the results.

\section{References}

1. Do Espírito Santo, A.P.E.; Perego, P.; Converti, A.; Oliveira, M.N. Influence of milk type and adittion of passion fruit peel powder on fermetation kinetics, texture profile and bacterial viability in probiotic yoghurts. LWT-Food Sci. Technol. 2012, 47, 393-399. [CrossRef]

2. Córdova, K.R.V.; Gama, T.M.M.T.B.; Winter, C.M.G.; Kaskantzis Neto, G.; Freitas, R.J.S. Características físico-químicas da casca do maracujá amarelo (Passiflora edulis flavicarpa Degener) obtida por secagem. CEPPA Bull. 2005, 23, 221-230. [CrossRef]

3. Morais, D.R.; Rotta, E.M.; Sargi, S.C.; Bonafe, E.G.; Suzuki, R.M.; Souza, N.E.; Matsushita, M.; Visentainer, J.V. Proximate composition, mineral contents and fatty acid composition of different parts and dried peels of tropical fruits cultivated in Brazil. J. Braz. Chem. Soc. 2017, 28, 308-318. [CrossRef]

4. Ambigaipalan, P.; de Camargo, A.C.; Shahidi, F. Phenolic compounds of pomegranate byproducts (outer skin, mesocarp, divider membrane) and their antioxidant activities. J. Agric. Food Chem. 2016, 64, 6584-6604. [CrossRef] [PubMed] 
5. Ambigaipalan, P.; de Camargo, A.C.; Shahidi, F. Identification of phenolic antioxidants and bioactives of pomegranate seeds following juice extraction using HPLC-DAD-ESI-MSn. Food Chem. 2017, 221, 1883-1894. [CrossRef] [PubMed]

6. De Oliveira, W.P.; Biasoto, A.C.T.; Marques, V.F.; Santos, I.M.; Magalhaes, K.; Correa, L.C.; Negro-Dellacqua, M.; Miranda, M.S.; de Camargo, A.C.; Shahidi, F. Phenolics from winemaking by-products better decrease VLDL-cholesterol and triacylglycerol levels than those of red wine in Wistar rats. J. Food Sci. 2017, 82, 2432-2437. [CrossRef] [PubMed]

7. Ayoub, M.; de Camargo, A.C.; Shahidi, F. Antioxidants and bioactivities of free, esterified and insoluble-bound phenolics from berry seed meals. Food Chem. 2016, 197, 221-232. [CrossRef] [PubMed]

8. De Camargo, A.C.; Regitano-d'Arce, M.A.B.; Rasera, G.B.; Canniatti-Brazaca, S.G.; do Prado-Silva, L.; Alvarenga, V.O.; Sant'Ana, A.S.; Shahidi, F. Phenolic acids and flavonoids of peanut by-products: Antioxidant capacity and antimicrobial effects. Food Chem. 2017, 237, 538-544. [CrossRef] [PubMed]

9. Cazarin, C.B.B.; Rodriguez-Nogales, A.; Algieri, F.; Utrilla, M.P.; Rodriguez-Cabezas, M.E.; Garrido-Mesa, J.; Guerra-Hernandez, E.; Braga, P.A.D.; Reyes, F.G.R.; Marostica, M.R.; et al. Intestinal anti-inflammatory effects of Passiflora edulis peel in the dextran sodium sulphate model of mouse colitis. J. Funct. Foods 2016, 26, 565-576. [CrossRef]

10. Selani, M.M.; Bianchini, A.; Ratnayake, W.S.; Flores, R.A.; Massaroli, A.P.; de Alencar, S.M.; Canniatti Brazaca, S.G. Physicochemical, functional and antioxidant properties of tropical co-products. Plant Foods Hum. Nutr. 2016, 71, 137-144. [CrossRef] [PubMed]

11. Arioui, F.; Saada, D.J.; Cheriguene, A. Physicochemical and sensory quality of yogurt incorporated with pectin from peel of Citrus sinensis. Food Sci. Nutr. 2017, 5, 358-364. [CrossRef] [PubMed]

12. Toledo, N.M.V.; Nunes, L.P.; Silva, P.P.M.; Spoto, M.H.F.; Canniatti-Brazaca, S.G. Influence of pineapple, apple and melon by-products on cookies: Physicochemical and sensory aspects. Int. J. Food Sci. Technol. 2017, 52, 1185-1192. [CrossRef]

13. Miocinovic, J.; Tomic, N.; Dojnov, B.; Tomasevic, I.; Stojanovic, S.; Djekic, I.; Vujcic, Z. Application of new insoluble dietary fibres from triticale as supplement in yoghurt-Effects on physico-chemical, rheological and quality properties. J. Sci. Food Agric. 2018, 98, 1291-1299. [CrossRef] [PubMed]

14. Clemens, R.; Kranz, S.; Mobley, A.R.; Nicklasm, T.A.; Raimondi, M.P.; Rodriguez, J.C.; Slavin, J.L.; Warshaw, H. Filling America's fiber intake gap: Summary of a roundtable to probe realistic solutions with a focus on grain-based foods. J. Nutr. 2012, 142, S1390-S1401. [CrossRef] [PubMed]

15. Karnopp, A.R.; Oliveira, K.G.; de Andrade, E.F.; Postingher, B.M.; Granato, D. Optimization of an organic yogurt based on sensorial, nutritional, and functional perspectives. Food Chem. 2017, 233, 401-411. [CrossRef] [PubMed]

16. Ramos, L.R.; Santos, J.S.; Daguer, H.; Valese, A.C.; Cruz, A.G.; Granato, D. Analytical optimization of a phenolic-rich herbal extract and supplementation in fermented milk containing sweet potato pulp. Food Chem. 2017, 221, 950-958. [CrossRef] [PubMed]

17. Elleuch, M.; Bedigian, D.; Roiseux, O.; Besbes, S.; Blecker, C.; Attia, H. Dietary fibre and fibre-rich by-products of food processing: Characterisation, technological functionality and commercial applications: A review. Food Chem. 2011, 124, 411-421. [CrossRef]

18. Sharma, S.K.; Bansal, S.; Mangal, M.; Dixit, A.K.; Gupta, R.K.; Mangal, A.K. Utilization of food processing by-products as dietary, functional, and novel fiber: A review. Crit. Rev. Food Sci. Nutr. 2016, 56, 1647-1661. [CrossRef] [PubMed]

19. Hoppert, K.; Zahn, S.; Jaenecke, L.; Mai, R.; Hoffmann, S.; Rohm, H. Consumer acceptance of regular and reduced-sugar yogurt enriched with different types of dietary fiber. Int. Dairy J. 2013, 28, 1-7. [CrossRef]

20. Yi, T.; Huang, X.; Pan, S.; Wang, L. Physicochemical and functional properties of micronized jincheng orange by-products (Citrus sinensis Osbeck) dietary fiber and its application as a fat replacer in yogurt. Int. J. Food Sci. Nutr. 2014, 65, 565-572. [CrossRef] [PubMed]

21. Raju, P.N.; Pal, D. Effect of dietary fibers on physico-chemical, sensory and textural properties of Misti Dahi. J. Food Sci. Technol. 2014, 51, 3124-3133. [CrossRef] [PubMed]

22. Perina, N.P.; Granato, D.; Hirota, C.; Cruz, A.G.; Bogsan, C.S.B.; Oliveira, M.N. Effect of vegetal oil emulsion and passion fruit peel-powder on sensory acceptance of functional yogurt. Food Res. Int. 2015, 70, 134-141. [CrossRef] 
23. Tamime, A.Y.; Robinson, R.K. Tamime and Robinson's Yogurt: Science and Technology; CRC Press: Boca Ratón, FL, USA, 2007.

24. Bamforth, C.W.; Ward, R.E. The Oxford Handbook of Food Fermentations; Oxford University Press: New York, NY, USA, 2014.

25. IDF-International Dairy Federation. Fermented Milks-Determination of Titratable Acidity-Potentiometric Method; IDF 150:2012; BSI: London, UK, 2012.

26. AOAC-Association of Official Analytical Chemists. Official Methods of Analysis of AOAC International; AOAC International: Gaithersburg, MD, USA, 2005.

27. Asp, N.G.; Johansson, C.G.; Hallmer, H.; Siljestroem, M. Rapid enzimatic assay of insoluble and soluble dietary fiber. J. Agric. Food Chem. 1983, 31, 476-482. [CrossRef] [PubMed]

28. Dello Staffolo, M.; Bertola, N.; Martino, M.; Bevilacqua, A. Influence of dietary fiber addition on sensory and rheological properties of yogurt. Int. Dairy J. 2004, 14, 263-268. [CrossRef]

29. Downes, F.P.; Ito, K. Compendium of Methods for the Microbiological Examination of Food; American Public Health Association: Washington, DC, USA, 2001.

30. Stone, H.S.; Sidel, J.L. Sensory Evaluation Practices; Academic Press: Orlando, FL, USA, 1993.

31. Lawless, H.T.; Heymann, H. Sensory Evaluation of Food: Principles and Practices; Springer Science \& Business Media: New York, NY, USA, 2010.

32. Meilgaard, M.C.; Civille, G.V.; Carr, B.T. Sensory Evaluation Techniques; CRC Press: Boca Ratón, FL, USA, 2006.

33. Almaraz, R.S.; Fuentes, M.M.; Milla, S.P.; Plaza, B.L.; Lopez, L.M.B.; Candela, C.G. Fiber-type indication among different pathologies. Nutr. Hosp. 2015, 31, 2372-2383. [CrossRef]

34. Bingham, S.A.; Day, N.E.; Luben, R.; Ferrari, P.; Slimani, N.; Norat, T.; Clavel-Chapelon, F.; Kesse, E.; Nieters, A.; Boeing, H.; et al. Dietary fibre in food and protection against colorectal cancer in the European prospective investigation into cancer and nutrition (EPIC): An observational study. Lancet 2003, 361, 1496-1501. [CrossRef]

35. Eshak, E.S.; Iso, H.; Date, C.; Kikuchi, S.; Watanabe, Y.; Wada, Y.; Wakai, K.; Tamakoshi, A.J.S.G. Dietary fiber intake is associated with reduced risk of mortality from cardiovascular disease among Japanese men and women. J. Nutr. 2010, 140, 1445-1453. [CrossRef] [PubMed]

36. Post, R.E.; Mainous, A.G.; King, D.E.; Simpson, K.N. Dietary fiber for the treatment of type 2 diabetes mellitus: A meta-analysis. J. Am. Board Fam. Med. 2012, 25, 16-23. [CrossRef] [PubMed]

37. Li, Y.; Hruby, A.; Bernstein, A.M.; Ley, S.H.; Wang, D.D.; Chiuve, S.E.; Sampson, L.; Rexrode, K.M.; Rimm, E.B.; Willett, W.C.; et al. Saturated fats compared with unsaturated fats and sources of carbohydrates in relation to risk of coronary heart disease: A prospective cohort study. J. Am. Coll. Cardiol. 2015, 66, 1538-1548. [CrossRef] [PubMed]

38. National Institutes of Health. Dietary Reference Intakes (DRIs): Recommended Dietary Allowances and Adequate Intakes, Elements. Available online: https:/ / www.ncbi.nlm.nih.gov/books/NBK56068/table/ summarytables.t3/?report=objectonly (accessed on 14 May 2018).

39. García-Perez, F.J.; Lario, Y.; Férnandez-López, J.; Sayas, E.; Pérez-Alvarez, J.A.; Sendra, E. Effect of orange fiber addition on yogurt color during fermentation and cold storage. Color Res. Appl. 2005, 30, 457-463. [CrossRef]

40. Tseng, A.; Zhao, Y. Wine grape pomace as antioxidant dietary fibre for enhancing nutritional value and improving storability of yogurt and salad dressing. Food Chem. 2013, 138, 356-365. [CrossRef] [PubMed]

41. Hashim, I.B.; Khalil, A.H.; Afifi, H.S. Quality characteristics and consumer acceptance of yogurt fortified with date fiber. J. Dairy Sci. 2009, 92, 5403-5407. [CrossRef] [PubMed]

42. Loveday, S.M.; Sarkar, A.; Singh, H. Innovative yoghurts: Novel processing technologies for improving acid milk gel texture. Trends Food Sci. Technol. 2013, 33, 5-20. [CrossRef]

43. Ramirez-Santiago, C.; Ramos-Solis, L.; Lobato-Calleros, C.; Peña-Valdivia, C.; Vernon-Carter, E.J.; Alvarez-Ramírez, J. Enrichment of stirred yogurt with soluble dietary fiber from Pachyrhizus erosus L. Urban: Effect on syneresis, microstructure and rheological properties. J. Food Eng. 2010, 101, 229-235. [CrossRef]

44. Aportela-Palacios, A.; Sosa-Morales, M.E.; Vélez-Ruiz, J.F. Rheological and physicochemical behavior of fortified yogurt with fiber and calcium. J. Texture Stud. 2005, 36, 333-349. [CrossRef]

45. Izadi, Z.; Nasirpour, A.; Garoosi, G.A.; Tamjidi, F. Rheological and physical properties of yogurt enriched with phytosterol during storage. J. Food Sci. Technol. 2015, 52, 5341-5346. [CrossRef] [PubMed] 
46. Brasil. Ministério da Saúde. Agência Nacional de Vigilância Sanitária. Resolução $\mathrm{n}^{\circ} 12$, de 02 de Janeiro de 2001. Aprova o Regulamento Técnico Sobre Padrões Microbiológicos Para Alimentos. Available online: http:/ / portal.anvisa.gov.br/documents/33880/2568070/RDC_12_2001.pdf/15ffddf6-37674527-bfac-740a0400829b (accessed on 14 May 2018).

47. Akalin, A.S.; Fenderya, S.; Akbulut, N. Viability and activity of bifidobacteria in yoghurt containing fructooligosaccharide during refrigerated storage. Int. J. Food Sci. Technol. 2004, 39, 613-621. [CrossRef]

48. FAO/WHO-Food and Agriculture Organization of the United Nations/World Health Organization. Codex Alimentarius-Milk and Milk Products. 2011. Available online: http:/ / www.fao.org/docrep/015/ i2085e/i2085e00.pdf (accessed on 18 January 2018).

49. Ledenbach, L.H.; Marshall, R.T. Microbiological Spoilage of Dairy Products. In Compendium of the Microbiological Spoilage of Foods and Beverages; Sperber, W.H., Doyle, M.P., Eds.; Springer: New York, NY, USA, 2009.

50. De Camargo, A.C.; Regitano-d'Arce, M.A.B.; Gallo, C.R.; Shahidi, F. Gamma-irradiation induced changes in microbiological status, phenolic profile and antioxidant activity of peanut skin. J. Funct. Foods 2015, 12, 129-143. [CrossRef]

51. Shah, N.N.A.K.; Shamsudin, R.; Rahman, R.A.; Adzahan, N.M. Fruit juice production using ultraviolet pasteurization: A review. Beverages 2016, 2, 22. [CrossRef]

52. Vogado, C.O.; Leandro, E.S.; Zandonadi, R.P.; Alencar, E.R.; Ginani, V.C.; Nakano, E.Y.; Habú, S.; Aguiar, P.A. Enrichment of probiotic fermented milk with green banana pulp: Characterization microbiological, physicochemical and sensory. Nutrients 2018, 10, 427. [CrossRef] [PubMed]

53. Gahruie, H.H.; Eskandari, M.H.; Mesbahi, G.; Hanifpour, M.A. Scientific and technical aspects of yogurt fortification: A review. Food Sci. Hum. Well. 2015, 4, 1-8. [CrossRef]

54. Spínola, V.; Pinto, J.; Castilho, P.C. Identification and quantification of phenolic compounds of selected fruits from Madeira Island by HPLC-DAD-ESI-MS and screening for their antioxidant activity. Food Chem. 2015, 173, 14-30. [CrossRef] [PubMed] 